\title{
IMPROVEMENT OF TEACHER CREATIVITY THROUGH TRAINING OF LEARNING MEDIA FROM BAMBOO BASED LOCAL WISDOM IN KECAMATAN SELO-BOYOLALI
}

\author{
Dhita Paranita Ningtyas \\ dhita@trilogi.ac.id \\ Universitas Trilogi
}

\begin{abstract}
Learning media is one of supporting teaching and facilitate children to understand the learning given, Selo sub-district under the foot of Mount Merapi and merbabu which has a natural wealth of bamboo trees are abundant so it can be utilized as the main ingredient of making APE media for supporting learning in early childhood that are In Selo Boyolali sub-district. This research aims to make training of Educational Game Equipment development by using bamboo natural materials that are widely available in Selo Boyolali area and can be used as learning media in early childhood that can be integrated in accordance with the theme of learning. The research approach uses action research to see the results of improving the ability of teachers to increase in creativity make APE after the training held to make APE media with bamboo materials. The findings of this research, APE Media from bamboo can be used as the main media of APE for learning, so that it has an effect to improve teacher ability in making Educational Game Tool by using material from local wealth, as well as the increasing ability of teachers in creating using the media from natural materials.
\end{abstract}

Keywords: Teacher creativity; Training; Learning media from bamboo.

\section{INTRODUCTION}

\section{Background Of The Problems}

Learning media is the support of teachers to provide knowledge to children, so that children can better understand what will be discussed by teachers at the time of learning. Learning for early childhood should use concrete or imitative objects that resemble the original because the early childhood thinks from concrete to abstract so that the child must be introduced first with the original object and then to the mock object. learning media is an 
intermediary used to convey information or lessons with the aim to stimulate learners to learn. While the use of instructional media is the way that is done to convey information in the form of learning materials. Learning media as a means of conveying information has certain functions and characteristics that distinguish it from other communication media. In general, Sudiarjo and Gultom argue that, the learning media serves as a tool to convey learning materials and media functions as a channel of educational communication. A medium is said as a learning medium if it has certain characteristics that are suitable for use in learning. According to Gerlach and Ely, the inherent features of instructional media, including fixative, media recording ability, storing and reconstructing an event, manipulative enabling transformation of an event, as well as distributive enabling the delivery of messages indefinitely of space and time.

Educational game tools are needed to support teachers in providing learning that is fun and easy to understand by children. Understanding Educational Game Tools (APE) is a game tool that deliberately designed specifically for the benefit of education. Learning support tools do not have to be teachers to buy but teachers can create media from natural materials tailored to the learning that is being implemented, but teachers in Kecamatan Selo still can not maximize the natural wealth around them. From the above problems, the training was held to develop educative games by using bamboo that is safe, suitable for children and affordable.

The training is intended for all PAUD teachers (TK and Play Groups) throughout Selo sub-district to create their game media to make teachers more creative and efficient. Research on "Improving the Creativity of PAUD Teachers through Development of Educational Game Tools (APE) from Bamboo Se Kecamatan Selo" to see if with this training the ability of teachers in making game tools by utilizing the media of natural materials more creative. Creativity relates to the nature of a person in themselves, each person possessing a different level of creativity. Some of the defining definitions of the meaning of creativity include Conny Setiawan saying that creativity is a special condition, attitude, or circumstance. Thus as something unique in a person, researchers assume that creativity has been inherent in a person since the child was born that is influenced by the environment in which humans grew up. So the internal factors (offspring) and external (environment) play a role in fostering / nurturing one's creativity. When creative people are asked what makes them solve problems in new ways, they say that the ability to find something between seemingly unrelated elements plays an important role. This research uses the method of action research with two 
cycles to see the results of the researcher doing data retrieval technique using observation, interview, rubric of the work and the calculation of pre test and post test.

\section{RESEARCH AIM}

This research was conducted to teach PAUD teachers in Kecamatan Selo to make learning media from natural materials that exist around mainly is material from bamboo. From this research, knowing that training development of APE making with local wisdom material can improve teacher creativity in making learning media and understanding the step of increasing the creativity of teachers in making learning media with training development of APE making with materials of local wisdom

\section{METHODS}

\subsection{PROCEDURE}

The research method used is action research. Basically this action research uses Kemmis and MC Taggart procedures. This model is essentially a device or strand with a single device consisting of four components that are viewed as a spiral cycle and include stages: a) planning, b) action, c) observation, d) reflection (Kusuma, 2009). Action research according to Kusuma is a study conducted by the teacher of his own class by planning, implementing and reflecting on the action in collaborative and partisifatif with the aim of improving its performance as a teacher, so that student learning outcomes can be improved (Kusuma, 2009). Mills defines action research as freely interpreted by researchers as any systematic research done by teachers, school principals, school counselors, or other school staff in a teaching or learning environment to collect certain information about how their schools operate, how they teach, And how well students learn ( Mills, 2003).

In this study consists of 1 training cycle consisting of 4 days of training, 2 days and 2 days of practice. In this training the preliminary observation, planning of the material, the necessary actions to improve the ability of making the media for PAUD teachers in Selo subdistrict, observing with the observation and pre-test and test post test and the last is reflection of the activities that have been done whether by holding the training This improves the ability of teachers in making game media. 


\subsection{Technical Data Collection and Data Analysis}

Data collection techniques in the development of learning media are observation sheets, interviews, and questionnaires or questionnaires containing a number of written questions that are used to obtain information from respondents.Data analysis is done by using quantitative statistics, the data is presented in the form of tables and graphs. The data that have been collected will be processed using Likert scale with scale value 1-4. To interpret quantitative data using the following references:

\section{Score 4: Very Good}

Score 3-3.9: Good

\section{Score 2-2.9: Average}

\section{Score 1-1.9: Less Good}

The reference is used to interpret quantitative data into qualitative data generated, ie data in the form of statistical calculation results and interviews and observations that will be explained in the form of a deep description of the product development results.

\section{RESULTS AND DISCUSSIONS}

In the preliminary has been described that the purpose of this study is to improve the ability of teachers in creating with natural materials to create learning media. Results obtained by researchers from the results of observations and also the results of pre-test and post test that has been done by 37 teachers in Selo subdistrict obtained the following results:

Tabel 1. Result of the calculation pre test and post test

\section{The Results of the Calculation of Pre-test and Post test}

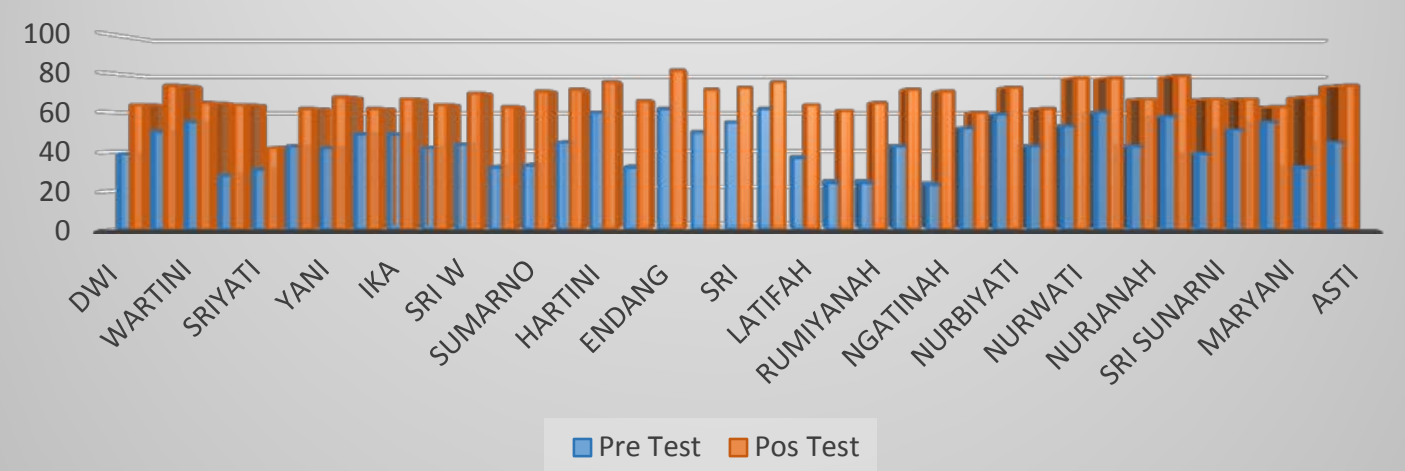


From the results of the above chart there is an increase in the ability of teachers in the understanding of learning media. The results obtained in each individual increased and they began to understand about the making of media in accordance with aspects of child development. Here are the photos created by teachers of Selo sub-district, made with basic materials of bamboo and modified with other natural media such as leaves, lidi, taro rod and others to introduce local wisdom of Selo district.

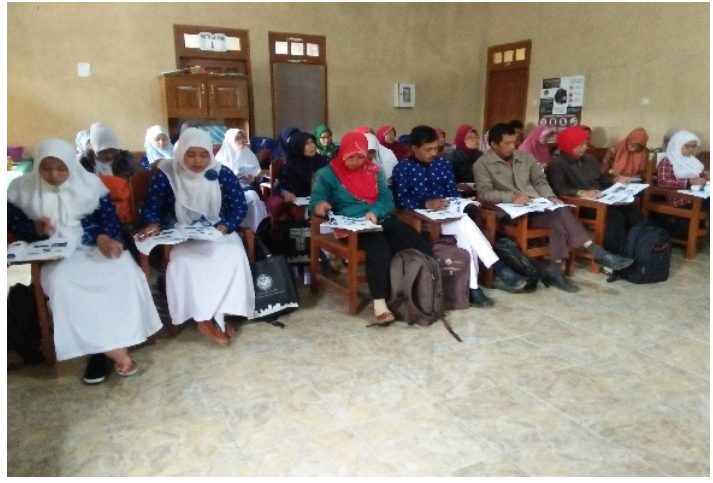

Figure 1. Theory Session at the time of training

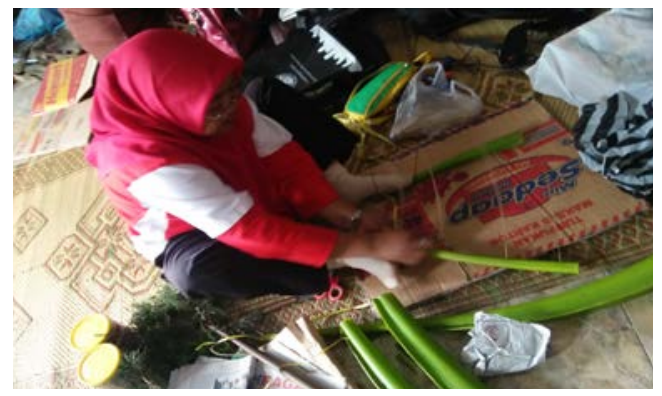

Figure 3. Working group make media

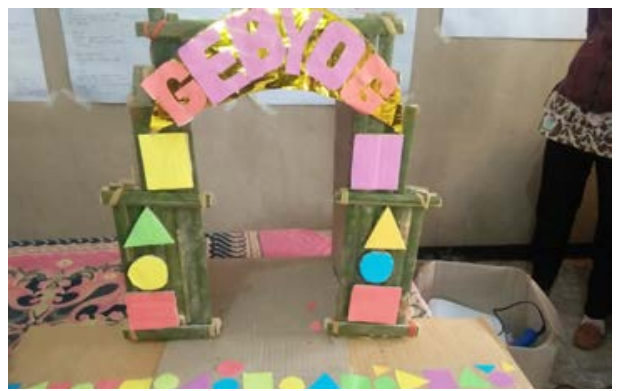

Figure 5. Exemple media from bamboo, make gebyog from bamboo for learn mathematic

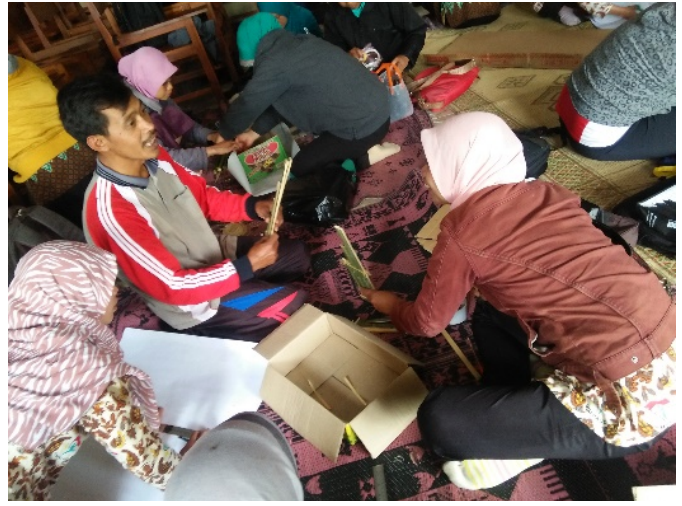

Figure 2. Discussion Session to make media from Bamboo

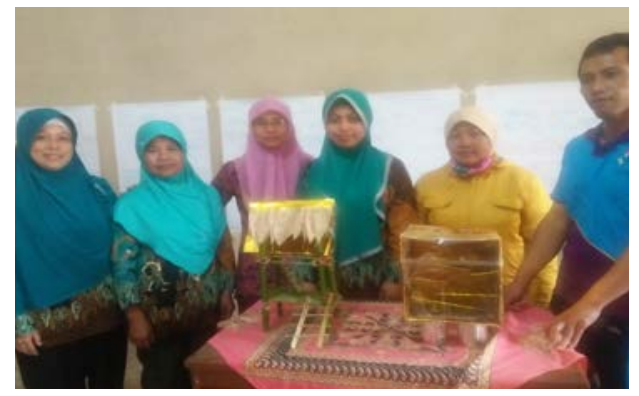

Figure 4. Presentation of the result made

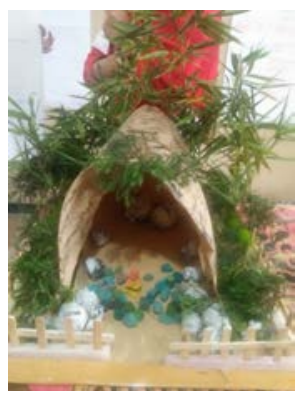

Figure 6. Example media from bamboo, make Raja Cave for learn 
The results of observations that researchers have done by looking and evaluating and interviewing with some teachers, obtained that the teacher is easier in finding ideas to perform activities with the media around them. Teachers are also more creative with the creation of goods from nature, used goods to be a powerful medium, meaningful and decent and safe for children. They are also more cost-efficient and do not pay for photocopying, creating media with materials that must be purchased and not creative because of copying the existing media.

\section{CONCLUSION}

The conclusion of this research is to increase the creativity of teachers by making the training of media making with this natural material become the means of the teacher to be more creative and easier for the teacher to give the learning to the child which is fun and in accordance with the local wisdom around Selo Boyolali area. Teach children to love culture and preserve the natural wealth around their homes. With such a training teachers feel very useful to them.

\section{REFERENCES}

Kusumah, W, Dwitagama, D. 2009. Mengenal Penelitian Kelas, Jakarta:Indeks.

Mills, Geoffrey E. 2003. Action Research a Guide for the Teacher Research . New Jersey:Merrill Prentice Hall

Sukiman. 2012. Pengembangan Media Pembelajaran. Yogyakarta: PT Pustaka Insan Madani.

Sutirman. 2013. Media dan Model-Model Pembelajaran Inovatif. Yogyakarta: Graha Ilmu.

Azhar Arsyad Media Pembelajaran (Jakarta:Grafindo Persada, 2004)

Semiawan, Coony R., I. Made Putrawan, I. Setiawan, 2004, Dimensi Kreatif dalam Filsafat Ilmu Bandung: PT Remaja Rosdakarya,

Sudiarjo, Sudarsono, Gultom, Eveline S., Media Pembelajaran sebagai Pilihan Dalam Strategi Pembelajaran

Tedjasaputra, Mayke, 2001, Bermain, Mainan, dan Permainan untuk Pendidikan Usia Dini, Jakarta: PT. Gramedia Widiasarana Indoneia, 